\title{
ACUTE MYOCARDIAL INFARCTION AND DIABETES MELLITUS
}

\section{AKUTNI INFARKT MIOKARDA I DIABETES MELLITUS}

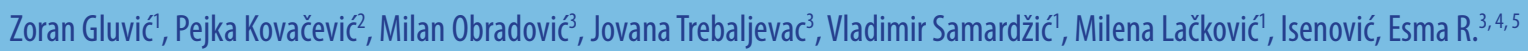

\section{Summary}

Acute myocardial infarction (AMI) is a clinical form of coronary heart disease, which occurs after coronary arteries' occlusion and irreversible ischemia progression leads to myocardial necrosis. Morbidity and mortality caused by cardiovascular comorbidities, including AIM, are greater in patients with insulin - dependent diabetes than in non - diabetes patients of the same age. One of the reasons for a higher mortality rate from AMl in patients with diabetes may be heart failure. In addition, patients with diabetes and AMI have an increased risk for poor therapy outcomes of AMI compared with non - diabetes patients, and the main reasons are endothelial dysfunction, prothrombotic state, a greater possibility of restenosis, negative vascular remodelling, increased protein glycosylation, and vascular matrix deposition. In this review, we provide an overview of recent literature data and practical knowledge related to the AMI in diabetic patients.

Keywords: Acute myocardial infarction, Diabetes mellitus.

\section{Sažetak}

Akutni infarkt miokarda (AIM) je klinički oblik koronarne bolesti srca, koji nastaje pri okluziji koronarne arterije, a ireverzibilna ishemija progredira do nekroze miokarda. Morbiditet i mortalitet od kardiovaskularnih komorbiditeta, uključujući AIM, je kod obolelih od insulin-nezavisnog dijabetesa veći nego kod nedijabetičara iste životne dobi. Jedan od razloga za veći mortalitet od infarkta miokarda kod dijabetičara može biti i srčana insuficijencija. Bolesnici sa diajbetesom i AIM imaju povećan rizik od lošeg ishoda terapije AIM u odnosu na nedijabetičare, a osnovni razlozi su endotelna disfunkcija, protrombotično stanje, veća mogućnost restenoze, negativnog vaskularnog remodelovanja, povećane glikolizacije proteinai depozicije vaskularnog matriksa. U okviru ovog preglednog članka, dat je prikaz najnovijih literaturnih podataka i praktičnih saznanja o AIM kod dijabetičnih bolesnika.

Ključne reči: Akutni infarkt miokarda, Diabetes mellitus

\section{AkUtni infarkt miokarda}

Akutni infarkt miokarda (AIM) je klinički oblik koronarne bolesti srca, koji nastaje pri okluziji koronarne arterije, pa ireverzibilna ishemija progredira do nekroze miokarda. AIM se karakteriše trajnim oštećenjem, kao i funkcionalnim i anatomskim gubitkom srčanog tkiva. Može imati veoma raznoliku kliničku sliku i elektrokardiografsku (EKG) prezentaciju, različite nivoe kardiospecifičnih enzima, kao i različitu prognozu (1).

\section{UZROCI AKUTNOG INFARKTA MIOKARDA}

Uobičajena patološka podloga AIM je erozija, fisura ili ruptura aterosklerotskog koronarnog plaka, udružena sa agregacijom trombocita koja vodi subtotalnoj ili totalnoj trombotičnoj koronarnoj okluziji. Aktivirani trombociti oslobađaju brojne vazokonstriktore, koji dalje remete koronarni protok stimulacijom glatkih mišićnih ćelija. Ruptura plaka omogućava interreakciju unutrašnje komponente plaka sa cirkulišućom krvi, a od svih komponenti tkivni faktor ima najjači efekat na potenciranje aktivacije trombocita (2). Studije sa intravaskularnim ultrazvukom su pokazale da takozvani vulnerabilni plakovi, sa rizikom od rupture kape, koji sužavaju lumen zahvaćenog krvnog suda $<50 \%$ u dijametru, prethode i predviđaju buduće akutne koronarne događaje u njihovoj okolini (3). Glavne odlike vulnerabilnosti plaka su veličina i sastav ateromatozne srži, debljina fibrozne kape, kao i akutna inflamacija.

Predilekciono mesto za rupturu plaka jeste rubni region, gde je fibrozna kapa najtanja i infiltrisana makrofagima. Na prethodno rupturiranom ili intaktnom plaku, može se javiti iznenadna tromboza usled promena u funkciji trombocita u procesima koagulacije $\mathrm{i} / \mathrm{ili}$ fibrinolize, što je važan mehanizam odgovoran za potpunu okluziju krvnog suda i pojavu infarkta (4). Zreli plakovi, naročito ako sadrže veću količinu fibroznog vezivnog tkiva, mogu kalcifikovati čak i u odsustvu komplikovanih lezija. Napredovanjem ateroskleroze, sve se više sužava lumen krvnog suda, remeti protok krvi i time raste rizik od daljeg oštećenja endotelnih ćelija. Suženje 
lumena krvnog suda je praćeno i tkivnom hipoksijom, a zbog smanjene elastičnosti krvnih sudova povećava se krvni pritisak i time mogućnost rupture izmenjenog zida krvnog suda $(5,6)$. Podela plakova, koja ima klinički značaj, je na komplikovane (vulnerabilne-nestabilne) i nekomplikovane (stabilne). Komplikovani su oni kod kojih je egzulcerisana površina (ulceracija na mestima gde je došlo do odvajanja dela lipidnog plaka) ili postoji prizidna tromboza (hipoehogena struktura apozicionog plaka) ili hemoragija u plaku (7). Ovi komplikovani plakovi su nestabilni i imaju tendenciju odvajanja delova sa mogućnošću embolizacije distalnih arterija.

\section{KLINIČKA SLIKA I TERAPIJA AKUTNOG INFARKTA MIOKARDA}

Akutni infarkt miokarda sa ST elevacijom (STEMI, engl. ST Segment Elevation Myocardial Infarction) nastaje ukoliko je okluzija koronarne arterije potpuna i trajna, usled čega prekid u cirkulaciji u toku $12 \mathrm{~h}$ uzrokuje kompletnu nekrozu tog segmenta miokarda. STEMI karakteriše crveni, uglavnom fibrinom bogat i mnogo stabilniji, okluzivni tromb. Pacijenti sa STEMI obično imaju kompletnu okluziju epikardne koronarne arterije. Primarni cilj u lečenju je rana reperfuziona terapija primenom fibrinolitika - farmakološka reperfuzija ili primarna perkutana koronarna intervencija (PCI, engl. Percutaneus Coronary Intervention) - mehanička reperfuzija. Inicijalna dijagnoza STEMI podrazumeva podatke o anginoznom bolu, perzistentnu elevaciju ST segmenta ili novi blok leve grane. Povišeni kardiospecifični enzimi potvrđuju dijagnozu, ali se terapija može započeti i bez podataka o povišenim kardiospecifičnim enzimima $(8,9)$.

Akutni infarkt miokarda bez ST elevacije (NSTEMI, engl. Non ST Segment Elevation Myocardial Infarction) nastaje ukoliko je okluzija potpuna, ali kratkotrajna i prolazna. Nekroza najčešće nije velika, a NSTEMI je obično udružen sa belim, trombocitima bogatim trombom, koji je samo parcijalno okluzivan. Mikrotrombi se mogu odvojiti i dovesti do nishodne embolizacije, uzrokujući miokardnu ishemiju i mikroinfarkte. Terapijska strategija kod NSTEMI uključuje antianginoznu, antiagregacionu i antikoagulantnu terapiju, dok je odluka o revaskularizaciji zasnovana na kliničkom stanju i stratifikaciji rizika. Invazivna strategija je indikovana kod pacijenata sa pozitivnim biomarkerima ili nestabilnom kliničkom slikom. Dva najvažnija faktora visokog rizika su depresija ST segmenta na aktuelnom EKG i povišen troponin (10). Fibrinoliza je kontraindikovana u ovoj grupi pacijenata, čak može biti i štetna i nosi veći mortalitet, što je pokazano randomizovanim studijama (11).

Da li će se kod pacijenta razviti STEMI ili NSTEMI zavisi od trajanja umanjenog koronarnog protoka, kvaliteta prisutnih kolaterala do ugroženog miokarda kao i od prirode formiranog tromba na mestu rupture plaka (9). Kada su miociti oštećeni, oštećene su njihove ćelijske mambrane, pa intracelularni proteini izlaze iz ćelije i mogu biti detektovani u krvi. Srčani troponin je u ovom trenutku najbolji marker miokardnog oštećenja u stratifikaciji rizika pacijenata sa bolom u grudima. Drugi biomarkeri takođe mogu biti od koristi, poput kreatin kinaze (CK), CK miokardno-moždane frakcije (CK-MB), mioglobina. Takođe, rastu vrednosti markera inflamacije, kao što su C-reaktivni protein (CRP) i fibrinogen, čiji su nivoi utoliko viši ukoliko je nekroza veća. Održavanje visokih vrednosti i posle akutne faze nosi veliki rizik nepovoljnog ishoda, odnosno komplikacija i mortaliteta nakon hospitalizacije (12). EKG promene su drugi važan kriterijum za postavljanje dijagnoze STEMI. Na osnovu nalaza EKG-a moguće je odvojiti bolesnike STEMI od onih sa NSTEMI. Važni za dijagnozu AIM su i anamnestički podaci: prethodna istorija o koronarnoj bolesti, pol, godine života, postojanje faktora rizika, njihov broj, kao i porodična predispozicija. Primarni ciljevi lečenja bolesnika sa AIM su redukcija veličine miokardne nekroze, očuvanje funkcije leve komore, sprečavanje nastanka srčane insuficijencije i prevencija životno ugrožavajućih komplikacija poput ventrikularne tahikardije, ventrikularne fibrilacije, simptomatske bradikardije, plućnog edema, kardiogenog šoka i mehaničkih komplikacija $\operatorname{AIM}(9,13)$.

\section{Diabetes mellitus}

Diabetes mellitus (DM) je metabolički poremećaj multiple etiologije koji karakteriše apsolutni ili relativni manjak insulina sa posledičnom hiperglikemijom i poremećajem metabolizma ugljenih hidrata, masti i proteina. Smatra se da preko $60 \%$ dijabetičara umire zbog kardiovaskularnih komplikacija, kao i da je 2-4 puta veća smrtnost od infarkta miokarda i moždanog udara (14). U DM postoji sadejstvo više nezavisnih faktora rizika za razvoj kardiovaskularnih komplikacija. Čitav niz činilaca ima direktan uticaj na pojavu DM. Tradicionalni faktori rizika, kao što su dislipidemije, hipertenzija i gojaznost, ne mogu u potpunosti da objasne ekscesivan rizik za vaskularna oboljenja, pa je utoliko važniji uticaj insulinske rezistencije, disfunkcije endotela, inflamacije ili mikroalbuminurije. Od značaja su, takođe, genetska predispozicija, kao i prisutnost štetnih životna navika (pušenje, fizička neaktivnost). Treba pomenuti i neke biohemijske faktore, koji su povišeni kod osoba sa DM, a koji doprinose akceleraciji ateroskleroze ili su reaktanti akutne faze (CRP i fibrinogen) (15).

AKUTNI INFARKT MIOKARDA I DiABETES MELLITUS

Obdukcione studije su pokazale da dijabetičari sa koronarnom bolešću imaju češće bolest dva ili tri krvna suda i manju incidencu jednosudovne koronarne bo- 
lesti, u odnosu na nedijabetičare (16). Aterosklerotske promene koronarnih arterija kod osoba sa DM su teže, difuzno rasprostranjene, često na malim krvnim sudovima, obično nepogodne za dilataciju (17). Uočeno je da osobe sa DM koje nisu pre imale AIM, imaju isti rizik od razvoja infarkta, kao i nedijabetičari, koji su preboleli AIM. Randomizovane studije su pokazale da dobra kontrola glikemije prevenira mikrovaskularne komplikacije, a smanjuje kardiovaskularni rizik kod dijabetičara (18). Važno je naglasiti dobru glikoregulaciju tokom AIM. U DIGAMI studiji (engl. Diabetes Mellitus Insulin Glucose Infusion in Acute Myocardial Infarction), osobe sa DM i AIM lečene intenziviranom insulinskom terapijom u periodu od tri meseca, imale su smanjenje ukupne jednogodišnje smrtnosti za oko $30 \%$ u odnosu na bolesnike koji su lečeni konvencionalnom insulinskom terapijom (19).

Morbiditet i mortalitet od KV komorbiditeta kod obolelih od insulinnezavisnog dijabetesa je 2-5 puta veći nego kod nedijabetičara iste životne dobi (20). Po GUSTO studiji, intrahospitalni mortalitet kod dijabetičara je bio $10,6 \%$, odnosno nedijabetičara $6,2 \%$ (21), što se ne razlikuje značajno od ukupnog mortaliteta u ovoj studiji (4\%). Smatra se da je višegodišnji dijabetes ekvivalent koronarnoj i cerebrovaskularnoj bolesti (20). Oko $75 \%$ obolelih od insulinnezavisnog dijabetesa umire od neke od makrovaskularnih komplikacija (koronarna, periferna ili cerebrovaskularna bolest). Kardiovaskularna bolest je odgovorna za smrt kod 75\% obolelih od insulinnezavisnog, odnosno 35\% kod insulinzavisnog dijabetesa (22). Jedan od razloga za veći mortalitet od infarkta miokarda kod dijabetičara nego kod nedijabetičara, može biti i srčana insuficijencija $(9,21,23)$.

Koronarna bolest kod obolelih od dijabetesa se javlja u ranijem životnom dobu nego kod nedijabetičara, sklonija je komplikacijama i češćim nepovoljnim ishodima. Objašnjenje bi se moglo kriti u difuznosti promena ili kasnijem javljanju obolelih lekaru po nastanku akutnog koronarnog sindroma, obzirom na nespecifične vidove ispoljavanja bolesti ili je ona, čak, asimptomat- ska („nema“). Uzrok ovoj pojavi je rani nastanak vegetativne neuropatije, kao mikrovaskularne komplikacije dijabetesa (20). Važno je napomenuti da je podatak o dijagnozi dijabetesa, najčešće i podatak o istovremenom početku tretmana dijabetesa. Često se dešava da, uprkos tome što ispitanici mnogo ranije znaju za postojanje povišenih vrednosti glikemija, ispitivanja u pravcu postojanja dijabetesa i njegovih komplikacija se tek kasnije sprovode (9).

\section{ZAKLJUČAK}

Terapijski cilj kod bolesnika sa DM i AIM je kao i kod ostalih pacijenata sa AIM- uspostaviti miokardnu perfuziju, očuvati i održati miokardnu funkciju, stabilizovati vulnerabilni plak, prevenirati rekurentne događaje kontrolom protrombotičke aktivnosti i usporiti progresiju aterosklerotske lezije (24). Bolesnici sa DM i AIM imaju povećan rizik od lošeg ishoda perkutane koronarne intervencije u odnosu na nedijabetičare. Osnovni razlog za to jeste endotelna disfunkcija, protrombotično stanje, veća mogućnost restenoze, negativnog vaskularnog remodelovanja, povećane glikolizacije proteina i depozicije vaskularnog matriksa. Ovi mehanizmi su potencirani hiperglikemijom i hiperinsulinemijom. DM je klinički faktor rizika za nastanak rane in-stent tromboze, ozbiljne komplikacije sa visokom smrtnošću. Rezidualna trombocitna reaktivnost i sklonost agregaciji, koja zaostaje i pored sprovedene terapije oralnim trombocitnim inhibitorima, važan je faktor u nastanku rane in-stent tromboze (25). Buduće studije u smeru praćenja efekata AIM kod bolesnika sa dijabetesom su neophodne kako bi se dotančina razjasnili mehanizmi veze, koja postoji između AMI i dijabetesa.

\section{ZahVALnica}

Ovaj rad je jednim delom podržan projektom broj 173033 (E.R.I.) finansiranim od strane Ministarstva prosvete, nauke i tehnološkog razvoja.

\section{Literatura}

1. Vasiljević, ed. Akutni koronarni sindrom. ed. O. M., K. V., and B. B.2011, Zavod za udžbenike. 428-59.

2. Krakow EF, Ginsberg JS, and C. MA., Arterial thromboemolism., in Hematology: Basic Principles and Practice. 5th ed., Hoffman R, et al., Editors. 2009, Elsevier Philadelphia. p. 2055-65.

3. Mehta, R.H., et al., Achieving rapid reperfusion with primary percutaneous coronary intervention remains a challenge: insights from American Heart Association's Get With the Guidelines program. Am Heart J, 2008. 155(6): p. 1059-67.

4. Konkle, Simon, and Schafer, Hemostasis, thrombosis, fibrinolysis and cardiovascular disease, in Braunwald's Heart Disease: a textbook of cardiovascular medicine, B. RO., et al., Editors. 2008, Saunders Elsevier. p. 2049-78.

5. NCEP, T.R.o., Executive Summary of The Third Report of The National Cholesterol Education Program (NCEP) Expert Panel on Detection, Evaluation, And Treatment of High Blood Cholesterol In Adults (Adult Treatment Panel III). JAMA, 2001. 285(19): p. 2486-97.

6. Savić, Dislipidemija i ateroskleroza, in Evaluacija i tretman dislipidemije-vodič za kliničku praksu, Savić, Editor 2004, Punta: Nis. p. 9-63.

7. Katouzian, A., et al., Challenges in atherosclerotic plaque characterization with intravascular ultrasound (IVUS): from data collection to classification. IEEE Trans Inf Technol Biomed, 2008. 12(3): p. 315-27.

8. Van de Werf, F., et al., Management of acute myocardial infarction in patients presenting with persistent ST-segment elevation: the Task Force on the Management of ST-Segment Elevation Acute Myocardial Infarction of the European Society of Cardiology. Eur Heart J, 2008. 29(23): p. 2909-45.

9. Kovačević, P., Epidemiološke, kliničke i angiografske karakteristike STEMI/NSTEMI kod obolelih od dijabetesa tip 2 tretiranih oralnom terapijom - rad uže specijalizacije iz Kardiologije. KBC Bežanijska kosa, Klinika za internu medicinu, Medicinski fakultet Univerziteta u Beogradu, 2015.

10. Bassand, J.P., et al., Guidelines for the diagnosis and treatment of nonST-segment elevation acute coronary syndromes. Eur Heart J, 2007. 28(13): p. 1598-660. 
11. investigators, T.I., Effects of tissue plasminogen activator and a comparison of early invasive and conservative strategies in unstable angina and non-Q-wave myocardial infarction. Results of the TIMI IIIB Trial. Thrombolysis in Myocardial Ischemia. Circulation, 1994. 89(4): p. 1545-56.

12. Danesh, J., et al., C-reactive protein and other circulating markers of inflammation in the prediction of coronary heart disease. $\mathrm{N}$ Engl J Med, 2004. 350(14): p. 1387-97.

13. Ostojić, et al., Akutni koronarni sindromi, in Nacionalni vodič dobre kliničke prakse za dijagnostikovanje i lečenje ishemijske bolesti srca. Beograd, R.s.k.z.i.i.i.v.d.k.p.M.z.R. Srbije, Editor 2012, AZUS. p. 24-36

14. Creager, M.A., et al., Diabetes and vascular disease: pathophysiology, clinical consequences, and medical therapy: Part I. Circulation, 2003. 108(12): p. 1527-32.

15. Fonseca, V.A., Risk factors for coronary heart disease in diabetes. Ann Intern Med, 2000. 133(2): p. 154-6.

16. Waller, B.F., et al., Status of the coronary arteries at necropsy in diabetes mellitus with onset after age 30 years. Analysis of 229 diabetic patients with and without clinical evidence of coronary heart disease and comparison to 183 control subjects. Am J Med, 1980. 69(4): p. 498-506.

17. Pajunen, P., et al., Angiographic severity and extent of coronary artery disease in patients with type 1 diabetes mellitus. Am J Cardiol, 2000. 86(10): p. 1080-5.

18. Protection, H., MRC/BHF Heart Protection Study of cholesterol lowering with simvastatin in 20,536 high-risk individuals: a randomised placebo-controlled trial. Lancet, 2002. 360(9326): p. 7-22.
19. Malmberg, K., et al., Randomized trial of insulin-glucose infusion followed by subcutaneous insulin treatment in diabetic patients with acute myocardial infarction (DIGAMI study): effects on mortality at 1 year. J Am Coll Cardiol, 1995. 26(1): p. 57-65.

20. Lalić, et al., Hronične komplikacije dijabetesa- specifičnosti dijagnostike i terapije, in Nacionalni vodič dobre kliničke prakse - Diabetes mellitus, M.z.R. Srbije, Editor 2013, AZUS: Beograd. p. 35-52.

21. investigators, t.G., An international randomized trial comparing four thrombolytic strategies for acute myocardial infarction. The GUSTO investigators. N Engl J Med, 1993. 329(10): p. 673-82.

22. Turner and Wass, Oxford Handbook of Endocrinology and Diabetes. Oxford University Press, 2009.

23. Turner, R.C., et al., Risk factors for coronary artery disease in non-insulin dependent diabetes mellitus: United Kingdom Prospective Diabetes Study (UKPDS: 23). BMJ, 1998. 316(7134): p. 823-8.

24. Wallentin, L., et al., Outcome at 1 year after an invasive compared with a non-invasive strategy in unstable coronary-artery disease: the FRISC II invasive randomised trial. FRISC II Investigators. Fast Revascularisation during Instability in Coronary artery disease. Lancet, 2000. 356(9223): p. 9-16.

25. Cannon, C.P., et al., Comparison of early invasive and conservative strategies in patients with unstable coronary syndromes treated with the glycoprotein IIb/IIIa inhibitor tirofiban. N Engl J Med, 2001. 344(25): p. 1879-87. 